6. Ostapenko G. Strukturni komponenty' gotovnosti majbutnix uchy'teliv fizy'chnoyi kul'tury' do organizaciyi zdorov'yazberezhuval'nogo navchal'novy'xovnogo seredovy'shha zagal'noosvitn'oyi shkoly' / G. Ostapenko, O. Cy'ganok, S. Zhestkov // Visny'k Zaporiz'kogo nacional'nogo un-tu. - Seriya: Fizy'chne vy'xovannya i sport. - 2012. - № 1 (7). - S. 78-85.

7. Sbruyeva A. A. [Porivnyal'na pedagogika] / Navchal'ny'j posibny'k. -K. Sumy': Redakcijno-vy'davny'chy'j viddil SDPU, 1999.

8. Slovny'k ukrayins'koyi movy' : v 11 tomax. - K. : Naukova dumka, 1972. - T. 3.

9. Klepko S. Integraciya i polimorfizm znannya u vy'shhij osviti / S. Klepko // Filosofiya osvity'. Naukovy'j chasopy's. - 2005. - № 2. - S. 20-36.

10. Krasovs'ka O. Pry'ncy'py' vidboru ta strukturuvannya zmistu profesijnoyi pidgotovky' majbutnix uchy'teliv pochatkovoyi shkoly' u galuzi my'stecz'koyi osvity' zasobamy' innovacijny'x texnologij / O. Krasovs'ka // Onovlennya zmistu, form ta metodiv navchannya i vy'xovannya $\vee$ zakladax osvity'. - 2014. - Vy'p. 9. - S. 37-40.
11. My'ronchuk N. Nastupnist' zmistu prakty'chnoyi pidgotovky' majbutnix uchy'teliv u VNZ / N My'ronchuk N. // Novi texnologiyi navchannya: nauk.metod. zb. / In-t innovacz. texnolog. i zmistu osvity' Ministerstva osvity' i nauky' Ukrayiny'. - K., 2014. - Vy'p. 81. - S. 106-110.

12. Nikolayenko S. Problema struktury' profesijno-pedagogichnoyi kul'tury' vchy'telya / S. Nikolayenko, S. Nikolayenko // Svitoglyad - Filosofiya Religiya. - 2013. - Vy'p. 4. - S. 277-285.

13. Ukrayins'ky'j pedagogichny'j slovny'k / za red. S. U. Goncharenko. - K. : Ly'bid', 1997.

14. Shmelev V. Optimizatsiya protsessa podgotovki studentov instituta fizicheskoy kulturyi $k$ professionalnoy deyatelnosti na osnove modeli spetsialista : avtoreferat dissertatsii na soiskanie uchenoy stepeni kand. ped. nauk : spets. 13.00.04 "Teoriya i metodika fizicheskogo vospitaniya, sportivnoy trenirovki, ozdorovitelnoy i adaptivnoy fizicheskoy kulturyi" , V. E. Shmelev. - Sankt-Peterburg, 2002.

Надійшла до редколегії 24.01.20

I. Usatova, PhD, Senior Lecturer,

V. Tkachenko, PhD, Associated Professor,

A. Vedmediuk, PhD, Associated Professor,

Bohdan Khmelnytsky National University of Cherkasy, Cherkasy, Ukraine.

\title{
BULUILDING CONTENT TRAINING TECHNOLOGIES OF PREPARING FUTURE SPECIALISTS FOR THE IMPLEMENTATION OF HEALTHCARE SAVING TECHNOLOGIES
}

\begin{abstract}
In the article on the basis of scientific and pedagogical sources the ways of perfection of the system of professional education with the purpose of preparing the future specialist for the practical realization of the idea of health saving of the nation at all stages of educational activity are analyzed and solved; the general structure of the system of quality assurance of education at the higher educational institution level is substantiated; determined the effective use of didactic principles; new approaches to the development of content, forms and methods of professional training of specialists in the new formation; the content of professional training of future specialists is investigated, covering the set of knowledge, skills and abilities, possession of which enables to work for the chosen type of profession; The set of principles, functions and factors that influence the content of the training is outlined in the curricula and programs of higher education institutions. An analysis of the structure of training of future specialists in higher education institutions is presented, which predicts mastery of a complex of professional and personal components of a future specialist. The peculiarities of preparation of future specialists for the implementation of health-saving technologies in the educational programs offered by educational establishments have been clarified. Types of variety of industrial and research practices are shown, forms and methods of teaching are named.

The content of the professional training of future specialists is characterized, the prerequisites for creating the concept of forming the future specialists' willingness to carry out innovative activity are outlined; conditions of effective use of health-saving technologies are formulated, essential characteristics and stages of preparation of future specialists in educational establishments are explained; The basic provisions are substantiated, the observance of which ensures the training of new formation specialists for the implementation of health-saving technologies. It is noted that the capacity for self-organization is the basis of successful professional activity of the future specialist and the educational disciplines of the programs of preparation of domestic higher education institutions are observed, the study of which contributes to the formation of the competence of selforganization. The essence of the problem under consideration and the technology of its solution are revealed.
\end{abstract}

Keywords: future specialist, general principles, health-saving technologies.

УДК 378:37:331.548

DOI: https://doi.org/10.17721/2415-3699.2020.12.16

Л. Левицька, канд. пед. наук, доц. Київський національний університет імені Тараса Шевченка, Київ

\section{ГЕНЕЗА ФОРМУВАННЯ ЦІННІСНИХ ОРІЕНТАЦІЙ СТУДЕНТСЬКОї МОЛОДІ В ІСТОРІЇ ВІТЧИЗНЯНОї ПЕДАГОГІЧНОї ДУМКИ (XX - ПОЧАТОК XXI СТОЛІТТЯ)}

Розглянуто історико-педагогічний аспект генези формування ціннісних орієнтацій студентської молоді в закладах вищої освіти України XX - початку XXI cm. Охарактеризовано передумови посилення тенденцій розвитку ідей та накопичення досвіду формування ціннісних орієнтацій у закладах вищої освіти України в XX- початку XXI ст. Розкрито сутність дефініції "ціннісні орієнтації". Розглянуто зміни, що відбулися в ціннісних орієнтаціях молоді в Україні. Систематизовано теоретичні ідеї й узагальнено досвід формування ціннісних орієнтацій студентської молоді в закладах вищої освіти України (XX - початок XXI cm.) і на цій основі обґрунтовано перспективи подальшого формування ціннісних орієнтацій студентської молоді в ЗВО України.

Ключові слова: цінності, ціннісні орієнтації, формування ціннісних орієнтацій, студентська молодь, заклади вищої ocsimu (3BO).

Постановка проблеми. Актуалізують означену проблему кризові реалії сьогоднішнього буття, невизначеність молоді у прийдешньому, різні теоретичні підходи до розгляду проблеми цінностей, реформування вищої освіти, зміна статусу культури й характеру людської діяльності та багато інших чинників. Формування системи цінностей молодих людей, їхнє трансформування в ціннісні орієнтації, визначені як пріоритетні завдання сучасних закладів вищої освіти, що задекларовано Законами України "Про освіту" і "Про вищу освіту", Національною стратегією розвитку освіти в Україні на 2012-2021 рр. та ін.

У формуванні особистості майбутнього фахівця ціннісні орієнтації визначають напрям і рівень активності та суттєво впливають на його професійні якості. Проблема ціннісних орієнтацій є однією з пріоритетних у сучасній науці. Зростаюча необхідність формування моральності та громадянської спрямованості особистості у процесі професійної підготовки молоді зумовлює підвищення наукового інтересу до вивчення закономірностей становлення ціннісних професійних орієнтацій студентської молоді.

Аналіз останніх досліджень і публікацій. На необхідність формування у студентської молоді ціннісних орієнтацій наголошувалось багатьма дослідниками (О. Антоновський, Т. Артімова, В. Желанова, Ю. Костєва, І. Марценюк, О. Сухомлинська та ін. 
Складний і суперечливий процес розвитку системи формування ціннісних орієнтацій студентської молоді у закладах вищої освіти України в досліджуваний період привертав увагу дослідників. Так, основні поняття теорії цінностей відображено у фрілософсько-психологічній літературі (дослідження В. Андрущенка, І. Аносова, В. Кременя, А. Маслоу, В. Молодиченка, В. Огнев'юка, К. Роджерса, В. Франкла, І. Фролова й ін.). Логіко-гносеологічний, соціально-культурний і психолого-педагогічний аспекти категорії "цінності" розкрито в дослідженнях І. Беха, М. Боришевського, В. Малахова, Б. Мещерякова, 3. Павлютенкової та ін. Із другої половини 80-х рр. минулого століття фрілософфські освітні засади аксіології розглянуто у працях І. Зязюна, В. Лутая, Є. Павлютенкова, Т. Троїцької, Г. Філіпчук та ін. Проблему фрормування ціннісних орієнтацій у вищій освіті висвітлено у працях О. Адаменко, Г. Васяновича, В. Вербеця, С. Гончаренка, С. Кримського, В. Сластьоніна, О. Сухомлинської й ін.

Теоретичному аналізу проблеми формування цінностей, ціннісних і професійно-ціннісних орієнтацій присвячено роботи психологів - Б. Ананьєва, В. Волкової, О. Дробницького, Г. Залеського, А. Здравомислова. Різні аспекти формування ціннісних орієнтацій особистості проаналізовані у працях педагогів: Е. Басіна, В. Бірулі, В. Дзюби, Н. Максимчук, Л. Морозової, О. Набоки, Л. Панченко, О. Ціхоцької, С. Шандрук, В. Шахрая.

Аналіз історико-фрілософської та психолого-педагогічної літератури свідчить, що натепер немає цілісного історико-педагогічного дослідження, предметом якого була б проблема ґенези формування ціннісних профресійних орієнтацій студентської молоді у ЗВО України (XX - початок XXIст.). До того ж цей аналіз свідчить про наявність низки суперечностей теорії і практики формування професійних цінностей: між прогресом суспільства й науки та втратою ціннісних орієнтирів у галузі освіти та виховання у вищій школі в досліджуваний період; між необхідністю в умовах євроінтеграції оновлювати систему підготовки конкурентоспроможних педагогів з урахуванням позитивного досвіду і надбань і недостатнім рівнем вивчення здобутків минулого в історико-педагогічному аспекті; між виховними можливостями навчальних предметів і педагогічної практики та недостатнім ступенем їхньої реалізації в практиці навчання та виховання в умовах ЗВО.

Отже, дослідження ґенези формування ціннісних професійних орієнтацій студентської молоді у закладах вищої освіти України в епоху корінних соціально-політичних перетворень XX - початку XXI ст. дозволить у сучасних умовах рефрормування вищої освіти України в контексті інтеграції до європейського освітнього простору вибрати оптимальні шляхи й механізми ефективного розвитку системи формування ціннісних професійних орієнтації студентської молоді в ЗВО

Мета статті - систематизувати теоретичні ідеї та узагальнити досвід формування ціннісних професійних орієнтацій студентської молоді в ЗВО України (XX - початок XXI ст.) і на цій основі обґрунтувати перспективи подальшого формування ціннісних професійних орієнтацій студентів у ЗВО України. Завдання дослідження: 1) на основі аналізу літературних джерел проаналізувати розвиток ідей формування ціннісних професійних орієнтацій студентської молоді у ЗВО України (XX - початок XXI ст.); 2) з'ясувати сутність дефініції "ціннісні орієнтації"; 3) визначити прогностичні тенденції формування ціннісних орієнтацій студентської молоді у ЗВО України.

Виклад основного матеріалу. Розвиток ідей формування ціннісних орієнтацій студентської молоді у ЗВО України досліджуваного періоду відбувався в контексті всіх суперечностей і складнощів розвитку вищої освіти XX - початку XXI ст. Цей період відображує логіку створення ідеологічних та освітньо-педагогічних стандартів радянської післясталінської епохи та початку розбудови української національної освіти пострадянських часів; це період інтенсивних пошуків і розробки, апробації моделей вищої школи майбутнього; період звернення до проблеми формування ціннісних професійних орієнтацій молоді. Пріоритет у її розв'язанні був зумовлений упровадженням педагогічних методів і технологій, спрямованих на формування ціннісних орієнтацій, активної громадянської позиції, соціальної мобільності та моральноетичних ідеалів молоді.

Аналіз літературних джерел [1-10] дає підстави констатувати, що означений період підкреслює значущість ролі молодого покоління в житті країни. Так, події двох останніх десятиліть стали переконливим свідченням того, що саме молодь визначає основний вектор розвитку української держави й українського суспільства. Саме молодь була ініціатором і зробила найвагоміший внесок у здобутки трьох українських революцій новітньої епохи: Революції на граніті 1990 р., яка відкрила шлях до відродження державності України; Помаранчевої революції 2004-2005 рр., яка продемонструвала світові прагнення українців до демократії і верховенства права; Революції гідності 2013-2014 рр., яка утвердила європейський цивілізаційний вибір народу. Саме студентська молодь першою стала на захист державного суверенітету і проголошених революцією ідеалів від сепаратизму і зовнішньої агресії.

Це, у свою чергу, посилює актуальність проблеми формування ціннісних орієнтацій студентської молоді в закладах вищої освіти. Адже аспекти формування ціннісних орієнтацій студентської молоді є надзвичайно важливими, зумовленими необхідністю посилення реалізації державної молодіжної політики України, оскільки молодь - одна з найбільш уражених соціальних груп у економічному, соціальному, культурному становищі, а тому потребує особливої уваги та підтримки, подальшого ґрунтовного дослідження, належного їй місця в педагогічній теорії і практиці.

У розробленій діалектико-матеріалістичній ціннісній концепції особистості, сфрормованій на основі марксистсько-ленінської теорії соціального розвитку (30-70-ті рр. XX ст.) виховання ціннісних орієнтацій у студентської молоді визначається як суспільні цінності, що формуються під впливом колективного досвіду (В. Бакіров, А. Ручка), заперечуючи залежність ціннісної свідомості від особливостей індивідуальної психіки людини, стверджуючи шляхи розв'язання аксіологічних проблем методами набуття соціологічних знань [8; 9].

Невідповідність між навчальним матеріалом суспільно-політичних дисциплін і власними спостереженнями й особистим досвідом викликала в молодого покоління другої половини 1940-х - першої половини 1950-х рр. сумніви, однак політика ідеологічного тиску сприяла тому, що серед окремих студентів з'являлися приховані від громадськості нестандартні погляди, фрормувалися інші цінності. Існуюча система створила сприятливі умови для розвитку у свідомості переважної частини юнаків і дівчат інстинкту самозбереження. Задля того, щоб вижити, вони приховували свої істинні погляди, думки, переконання. "Двовимірність" у поведінці була характерною рисою багатьох студентів означеного періоду.

Після завершення Другої світової війни політика радянського державно-політичного керівництва передбачала участь студентської молоді у трудовій діяльності на об'єктах народного господарства, вбачаючи "запоруку 
успіху підготовки висококваліфікованого, політично грамотного радянського спеціаліста в поєднанні навчання з виробничою практикою.

Дефріцит великої кількості робочих рук і кваліфікованих спеціалістів поповнюється шляхом активної участі студентів у роботі на народногосподарських об'єктах; радянське партійне керівництво, спираючись на комсомольський актив, виховувало у студентів "готовність переборювати труднощі, працювати там, де цього потребують інтереси Батьківщини".

У повоєнний час частішають критичні висловлювання студентства, що свідчить про гнучкість мислення молодих людей та існування студентської громадської думки, а також небайдужості до майбутнього держави, прагнення до якісних змін у соціально-економічній, культурній і політичній системі та розуміння неефективності і деградації командно-адміністративних методів управління державою. Критичне прийняття дійсності сприяло тому, що вже в подальші роки хрущовської "відлиги" в середовищі молоді активно почали відроджуватися національні ідеї, в Україні виникають опозиційні національні, й антидержавні студентські групи та легальні і нелегальні культурні молодіжні осередки.

Найбільша політична активність спостерігалася в середовищі західноукраїнського студентства, яке виступало проти русифікації та колективізації, і саме цей проміжок часу характеризується масовими виключеннями із ЗВО й арештами студентства. Усе ж варто зауважити, що серед основної маси студентства переважали лояльні суспільно-політичні настрої. Владні органи слідкували за студентськими настроями й ретельно контролювали всі можливі прояви незадоволення існуючими порядками, адже публічне обговорення реалій життя викликало в керівництва острах перед імовірною появою відкритої опозиції.

У другій половині XX ст. вітчизняна педагогічна наука акцентувала увагу на вивченні ціннісної проблематики. Найяскравіше це виявилось у діяльності В. Сухомлинського, який морально-етичне виховання взяв за основу духовного життя людини, а інші напрями виховання поставив у пряму залежність від ціннісних орієнтацій.

На формування ціннісних орієнтацій студентів у ЗВО України значний вплив мали такі фактори: соціальноекономічні та політичні перетворення у країні та в світі, політика правлячої партії та уряду в галузі науки й освіти досліджуваного періоду. Значний вплив на еволюцію формування ціннісних орієнтацій студентської молоді зазначеного періоду мало виникнення в Західній Європі "ціннісного виховання" як напряму педагогічної теорії і практики (Д. Дьюі, М. Бубер, К. Роджерс, А. Маслоу, К. Бек та ін.).

Прихід у 1953 р. до влади М. С. Хрущова - як першого секретаря ЦК КПРС, згодом голови Ради Міністрів СРСР, що надало йому практично необмежені можливості, став початком задекларованих ним особисто кардинальних реформ в усіх галузях життя країни - економіці, політиці, ідеології, культурі, освіті. Центральною подією цього періоду став XX з'їзд КПРС (1956), на якому був розвінчаний культ Сталіна. У ці роки, можливо, уперше за часи існування СРСР партія зайнялася проєктуванням майбутнього держави, колективного майбутнього, висунувши ідею про те, що через 20 років радянські люди житимуть при комунізмі й випередять найрозвиненішу на той час країну - США за всіма показниками виробництва на душу населення (унаслідок - припинилася ізоляціоністська політика, зійшла нанівець ідеологія "холодної війни"; у країні почали виникати "товсті" суспільно-публіцистичні й художні журнали, публікуватися переклади зарубіжної літератури; усі ці процеси згодом назвуть "відлигою", а людей, які активно брали в цьому участь, - "шістдесятниками").

Невипадково в кінці 50-х рр. XX ст., що характеризується як ідеологічна "відлига", був відкритий вільний доступ до раніше недоступної вивченню наукової інформації; у ЗВО почали функціонувати кафедри етики, естетики, логіки, філософії релігії - фрілософських дисциплін нормативно-аксіологічного характеру, з'явились праці вітчизняних учених, які розглядали проблеми цінності та формування ціннісного відношення людини до світу.

Із середини 50-х - початку 60-х рр. КПРС ідеологічно спрямовувала роботу на моральне виховання молоді. Одним із головних напрямів КПРС визначала "виховання комуністичного ставлення до праці, яке, зазвичай, пов'язувалося із позитивним сприйняттям безоплатної роботи на благо держави" [3]. На відміну від вимог до комуністичної праці сталінського ідеального громадянина Радянського Союзу, який мусив не лише працювати на благо держави, а й викривати ворогів внутрішніх, які підривали могутність країни, у період хрущовської "відлиги" на перший план виходить праця "по-комуністичному", пов'язана з початком у країні науково-технічної революції: поєднання науки з технікою і виробництвом; використання комп'ютерної техніки та перехід від машинного виробництва до автоматизованого, від механічних технологій до хімічних, біохімічних, фрізичних; створення штучних синтетичних матеріалів; стирання меж між розумовою і фрізичною працею. Суттєво підвищується у суспільстві статус кваліфікованих робітників, рівень їхньої соціальної захищеності.

Варто зазначити, що в колишньому Радянському Союзі Україна виділялася тим, що в 50-80-х рр. XX ст. у республіці існувала досить широка мережа ЗВО, які готували фахівців для народної освіти. Із середини 50-х рр.в XX ст. з'явилися праці вітчизняних учених, які розглядали проблеми цінностей і формування ціннісних орієнтацій студентської молоді [5].

Це був період, коли в умовах суспільно-політичної "відлиги", критики культу Сталіна, повернення до ленінської спадщини позначилися демократичні тенденції в політичному, економічному й культурному житті країни, які стимулювали суспільну активність, розвиток ініціативи і творчого пошуку, реформаційні зміни у підготовці педагогічних фрахівців, створення нового типу школи школа-інтернат. Важливим завданням освіти цього періоду було здійснення у країні загальної обов'язкової середньої освіти, перехід на новий зміст удосконалення освітнього процесу і виховання.

Епоха "відлиги" стала важливим переломним моментом вітчизняної історії, тому ії різнобічне дослідження дозволяє пояснити подальший розвиток України. Особлива увага на той час приділялася студентській молоді та інтелігенції.

Менталітет "шістдесятників" формувався у 1950-х середині 1960-х рр. Саме в цей період проблеми розвитку радянської молоді були предметом пильної уваги сучасників. Останні намагалися виявити і проаналізувати основні тенденції іï розвитку, дослідити сам феномен молодіжної активності, а також сформувати певну систему цінностей, дати молоді ті загальні орієнтири, які визначалися домінуючою комуністичною ідеологією. Через це, основна частина публікацій була пов'язана не стільки $з$ дослідженням самої молоді, скільки з роз'ясненням і популяризацією молодіжної політики правлячої комуністичної партії, визначенням завдань єдиної загальносоюзної організації комуністичної молоді - ВЛКСМ, потребами поточної агітації та інструктування [6]. 
Для покоління "шістдесятників" у другій половині 1950-х рр. були характерні ентузіазм, розвинене почуття соціальної відповідальності, віра в історичну зумовленість комунізму, пріоритет загального над приватним, романтичне уявлення про революцію і війну, творчий підйом. Під впливом різних факторів світогляд покоління змінився до середини 1960-х рр. На зміну перерахованих якостей прийшли такі явища, як відхід в особисте життя, розчарування в реформаторський потенціал країни й демагогії керівництва, феномен двозначності, споживацьке ставлення до партії як до необхідного щабля кар'єрного зростання, страх перед керівництвом і каральними органами. Побоювання втратити досягнуті спокій і комфорт, а також впевненість у стійкості системи та неможливості змін привели до високого рівня конформізму всередині покоління.

Варто зазначити, що пошуки ідентичності "шістдесятників" відбувалися і в галузі художньої літератури. Постановка проблеми відмінних рис конкретного покоління була неможлива в офріційній радянській історіографії.

Соціологічні дослідження містять дані про "народження в масовій, переважно молодіжній, свідомості абсолютно нової цінності - вільної діяльності, що здійснюється вільними суб'єктами і яка характеризується високою ефективністю" [7].

Зростання інтересу молодих людей до отримання освіти відобразилось в істотному збільшенні прийому до закладів вищої освіти: у 1960-1965 рр. він майже подвоївся. Це дозволило забезпечити безболісне оновлення кадрів фахівців, підготовлених в 30-ті рр., які об'єктивно вибували зі сфрери праці.

Важливо також відзначити, що суспільно-політична активність молоді вивчалася під неодмінним гаслом боротьби з буржуазною ідеологією. У цій обстановці якомога плідніше (проте обмежено) міг розвиватися тільки напрям, який займався критикою буржуазних теорій молоді. Зазначається, що цьому напрямі досліджень заважало те, що вітчизняними дослідниками тут відстоювалася теза про те, що радянська молодь не має нічого спільного із західними однолітками.

Величезний вплив на молодь мали прочеси демократизації, гуманізації суспільного життя у СРСР. XX з'їзд КПРС викликав значне зростання політичної активності молоді, причому в основному в межах соціалістичного вибору. Незважаючи на прояви інакомислення, у молодіжному середовищі відбулося зміцнення соціалістичних цінностей, склалося особливе стверджувальне світовідчуття, у контексті якого цілком реальною здавалася навіть утопічна перспектива швидкого комунізму.

Констатуючи зростання громадської активності та актуалізацію питань політичної самореалізації молодого покоління в 1953-1964 рр., слід, однак зазначити, що молоде покоління в СРСР перебувало під жорстким політичним наглядом влади, яка контролювала його ідейні формування, світогляд, політичні установки. Загалом, це дозволяло забезпечувати адекватне завдання режиму соціалізацію нових поколінь.

У роки "відлиги" влада як і раніше приділяли особливу увагу всьому, що "негативно позначається на комуністичному вихованні молоді". Проте, відмова від терору, проголошення завдань комуністичного будівництва дали новий імпульс молодіжної активності. Молодь була впевнена в послідовній демократизації. Існуючі проблеми лише стимулювали пошук ідеалів, звертаючи погляд молоді й до романтики 20-30-х рр., і до праць класиків марксизму-ленінізму, і до повсякденної героїки.

Студенти початку 1950-х рр., на відміну від студентів середини 1950-х рр., до навчання ставилися сумлінніше.
Водночас кількість бажаючих навчатися в університетах збільшувалася, про що свідчать великі конкурси при вступі. Отриманню якісних знань і ставлення до навчання у внз сприяла і школа, яка закладала фундамент для отримання нових знань. Велику роль у формуванні світогляду студентів відігравала особистість викладача. Саме завдяки професіоналізму викладацько-професорського складу створювалося особливе світосприйняття, розширювався науковий світогляд, вироблялося ставлення до майбутньої професії; від цього залежала і якість отриманих знань [8].

Однак у досліджуваний період спостерігається розчарування в навчальному процесі студентів. Воно обумовлювалося специфікою політичної системи у країні, яка постійно намагалася втручатися в академічне життя студентства та створювала морально-психологічний дискомфорт. Поряд із тим домінувало прагнення отримати вищу освіту задля майбутнього, адже вища освіта відкривала в перспективі більше життєвих можливостей.

3ВО України були "кузнями" нових комуністичних кадрів, тому студенти перебували під особливим ідеологічним контролем влади. Незважаючи на такий чинник, реальні суспільно-політичні настрої студентської молоді були різноманітний спектр поглядів, ідей, прагнень, які формувалися через надходження потоку інформації з офріційних джерел і "джерел-табу". Невід'ємними факторами впливу на формування свідомості та громадянської позиції студентства 1950-1960-х рр. були як внутрішньополітичні чинники, так і зовнішньополітичні.

Періодом студентської громадянської активності, коли переважали критичні настрої щодо політики держави, можна назвати 1950-1953 рр.; роками відносного спокою були 1954-1955 pp.

Свого піку патріотичне піднесення досягло в 1961 р., у зв'язку з польотом у космос Ю. Гагаріна ("абсолютно у всіх хлопчаків була впевненість в неминучості нашої перемоги і поразки Заходу"). В кінцевому рахунку, все це призвело до значного зростання загального рівня розвитку і суспільної активності покоління "відлиги".

Варто відзначити, що розгортання лібералізаційних процесів за правління М.Хрущова в основному були позитивно сприйняті та підтримані студентською молоддю, про що свідчить поява в 1958-1967 рр. серед студентів різних регіонів України значної кількості антидержавних, легальних і нелегальних альтернативних студентських груп, різних за характером (політичних, культурних, економічних). З'ясовано, що в період згортання лібералізаційних процесів студентство було незадоволене тоталітарним режимом, усе частіше висловлювало бажання покинути межі СРСР.

До середини XX ст. у вітчизняній літературі аксіологія визначалась як ідеалістичний напрям західноєвропейської фрілософрії, і лише в 60-ті рр. вітчизняна наука звернулась до вивчення ціннісної проблематики. Дослідниця Н. Ткачова відзначає, що за радянських часів у вітчизняній науковій літературі термін "цінність" довго не використовувався, оскільки вважався "дрібнобуржуазним" поняттям [6].

Значний внесок у дослідження проблеми виховання ціннісних орієнтацій майбутніх фахівців прослідковується в роботах видатного педагога А. Макаренка.

Встановлено, що в перші роки хрущовської "відлиги" політика радянської держави та правлячої партії щодо формування ціннісних орієнтацій студентської молоді у ЗВО спрямовувалася на організацію морального, національного, патріотичного, атеїстичного, розумового, естетичного, фрізичного та сімейного виховання студентської молоді, передбачала активну участь студентів 
у роботі громадських організацій та установ, наукових товариств, виступи з публічними лекціями, сприяння всебічному розвитку особистості, яка втілює в життя рішення Комуністичної партії та Уряду, дотримується принципів "Морального кодексу будівника комунізму".

У 1960-ті рр. особлива увага зверталась на вивчення системи ціннісних орієнтацій молоді, яка щойно розпочинала трудову діяльність; на працю, освіту та їхній взаємозв'язок; вивчалися орієнтації на різні сторони способу життя (сім'я, дозвілля тощо). До речі, цінність праці вважалась засобом здійснення життєвих планів і задоволенням інтересів особистості, вона була прямо пропорційною зростанню духовних і матеріальних потреб людини та обернено пропорційною можливості використовувати інші (нетрудові) засоби для їх задоволення.

Аналіз взаємодії ціннісних орієнтацій показав, що студенти, орієнтовані на сім'ю, ставлять на перше місце освіту, а орієнтовані на освіту - сім'ю. Отже, чільне місце в орієнтаціях, життєвих планах молоді в 1960-ті рр. посідали цінності освіти й сім'ї.

У 60-70-х рр. XX ст. визначаються основні тенденції розвитку університетської освіти: поглиблення науково-педагогічної підготовки освітніх кадрів, підвищення рівня професійно-педагогічної підготовки студентів. Відбулися реформи, які визначили особливості навчання на денній і заочній формах [3]. 70-ті pp. XX ст. визначаються як період зрілого соціалізму. У цей час значення ідейновиховної спрямованості не лише не зменшується, а, навпаки, зростає. Щодня відбувалися відчутні зміни в розвитку науки й техніки, оновленні соціально-економічних умов, зростанні свідомості народу. У цей час підвищувалися вимоги до вищої школи, покликаної підготувати не просто фахівців високої кваліфрікації для різних галузей народного господарства, а глибоко освічених, здорових фрізично й морально, ідейно переконаних патріотів своєї Батьківщини, які не мислять свого життя поза колективною діяльністю, тобто виховати соціально активну особистість нового, соціалістичного суспільства [3].

Варто констатувати, що у соціалістичному суспільстві в умовах науково-технічного прогресу цей процес відбувався у постійному виховному впливі на студентів із боку керівництва, органів самоврядування, що не завжди відповідало потребам студентів - їхнім запитам, інтересам, захопленням, духовному світу. Значна увага приділялась гуманістичній ціннісній орієнтації як засобу виховання й особистісного саморозвитку.

Структура фрормування ціннісних профресійних орієнтацій перебувала в постійному розвитку $і$ перетворенні; формування ціннісних професійних орієнтацій студентської молоді на етапі навчання у ЗВО - цілісний процес, для забезпечення оптимізації якого у структурі професійної готовності виділяються такі компоненти: мотиваційний, інтелектуальний, змістовий, пізнавальний, емоціональний, вольовий, операційний, ціннісно-смисловий, оцінний, комунікативний, дидактичний та ін.; поряд із принципом колективізму, активно втілювався в життя принцип індивідуального підходу в контексті ситуативно-коригувальної діяльності педагога, який сприяв ефективному формуванню ціннісних професійних орієнтацій студентської молоді. Студентська молодь на питання "Які життєві цінності є для Вас пріоритетними?" зазначала: кохання - 62,6 \% опитаних, сім'я - 54,8 \%, здоров'я - 38,5 \%, матеріальний достаток - 35,9\%, улюблена робота - 23,9\%, освіта - 22,6\%, чисте сумління $13,8 \%$, корисність людям - $9 \%$, творчість - 5,3\% [2]. І3 цих даних бачимо, що превалювали (та й превалюють зараз) особисті пріоритети, турботи про себе й сім'ю.
Основним предметом досліджень студентської молоді 1970-х і 1980-х рр. були цінності трудової діяльноcmi. Так, молодь 1970-х віддавала перевагу змістовим характеристикам праці; далі йшли важливі цінності, пов'язані з можливістю задоволення потреб духовного зростання; на останньому ж місці опинилися характеристики становища спеціаліста (службове зростання тощо).

Отже, зберігаючи переважаючу орієнтацію на змістовність праці, молодь 1970-х рр. здебільшого, ніж попередня їі когорта (1960-ті рр.), висунула на перший план колективістсько орієнтовані цінності.

У 1971-1975 рр. соціологічною лабораторією Харківського університету проводилося дослідження, яким було охоплено 6349 студентів ХДУ і 3135 студентів п'яти внз Харкова. На питання "Що ви вважаєте для себе головним у житті?": 93,5 \% всіх опитаних відповіли: "цікава, улюблена робота", 65,9 \% - "робота, що приносить користь суспільству, колективу; $64 \%$ - "переконаність у правоті ідей нашого суспільства"; лише 1-3 \% вважали, що головне в житті "досягнення власного добробуту". За результатами такого ж опитування у 1982 р., на перше місце серед життєвих цінностей студентської молоді виступає "цікава робота" - 75,3 \%, "сімейне щастя, щастя в коханні, діти" - 66,4 \%, "повага до людей" - 43,6 \%, "повне матеріальне благополуччя" - 31,6 \% опитаних.

Отже, варто зазначити, що у 1980-х рр. серед цінностей у сорері праці серед студентської молоді на перший план виходять цінності профресійного зростання, матеріального добробуту та суспільного визнання. Що стосується цінностей творчості, самоствердження, суспільної користі, то їхнє місце в системі ціннісних орієнтацій було малозначущим.

Як показав порівняльний аналіз досліджень, матеріальна забезпеченість як иінність із переходом від покоління до покоління здобувала все вищий ране. Можливо, це пов'язано з тим, що радянське суспільство поступово втрачало статус "суспільства рівних можливостей", а тому молодь найбільше цінувала у професії можливість одержувати високі доходи, аніж її суспільну користь.

Друга половина 80-х - початок 90-х рр., відзначаються реформуванням у системі вищої освіти, поступовим переосмисленням шляхів розвитку освіти: в авторитарній державі зароджується незвичний для радянського суспільства напрям - педагогіка співробітництва. Загальним принципом теорії педагогічного співробітництва було визначено практичне втілення ідеї створення узгодженого тандему педагога та вихованця. Основне ідейно спрямоване завдання педагога - виховати дитину, яка стає центральною ланкою освітнього процесу, однодумцем педагогу, вихователям, батькам у своєму вихованні та навчанні, рівноправним учасником освітньої діяльності, відповідальною за результати власної освітньо-виховної діяльності. Гуманно-особистісний підхід педагога до дитини докорінно змінює педагогіку вимог на педагогіку відношень, що забезпечує єдність навчання та виховання.

Розвиток ціннісних професійних орієнтацій пов'язаний із набуттям Україною державної незалежності: Верховною Радою Української РСР 16 липня 1990 р. була прийнята "Декларація про державний суверенітет України", у якій було проголошено "державний суверенітет України як верховенство, самостійність, повноту і неподільність влади Республіки в межах її території та незалежність і рівноправність у зовнішніх відносинах".

За результатами дослідження, проведеного в 1990 p. Інститутом соціології АН України серед жителів Києва віком від 16 до 30 років, рейтинг життєвих цінностей молоді мав такий вигляд: переважають особистісні пріори- 
тети, сім'я, друзі, житлові умови, робота, власне здоров'я. Це важлива тенденція, що характеризує зміни ціннісних орієнтацій молоді в 90-х рр. - відверта перевага індивідуалізму, акцент на особистісно-сімейних інтересах; молодь поступово відмовляється від колективістського способу життя. Якщо раніше такі цінності, як "повага оточуючих", "хороші стосунки в колективі", "повага інших" посідали 2-3 місця в ієрархії цінностей, то нині зовсім інша ситуація [6].

Соціально-економічний хаос 90-х рр. змінив акценти у сорормованій раніше системі цінностей, молоді люди бажають активно займатися підприємництвом, отримати професію й роботу, які обіцяють матеріальне благополуччя, життєвий успіх.

У 1993 р. із прийняттям Державної національної програми "Освіта" ("Україна XXI століття") було визначено основні напрями національного виховання в Українській державі, що відобразилося на фрормуванні ціннісних орієнтацій студентської молоді: формування в молоді і дітей світоглядної свідомості, ідей, поглядів, переконань, ідеалів, традицій, звичаїв, інших соціально значущих надбань вітчизняної і світової духовної культури.

Друга половина 90-х років - початок XXI ст. визначається здійсненням переходу від індустріального типу культури до інформаційного, який характеризується високим рівнем вимог освіти й науки, що пов'язано зі змінами в суспільно-політичному та соціально-економічному розвитку України відповідно до ії̈ нового державного статусу незалежної держави. Перехід до ринкової економіки, необхідність у збільшенні кількості фахівців, активне формування сучасних спеціальностей, зокрема й педагогічних, приводить до розширення кількості ЗВО, виникнення навчальних закладів, у яких навчання здійснюється за кошти фрізичних і юридичних осіб. У цих умовах відзначається відповідність вищої освіти сучасному етапу історичного розвитку цивілізації.

Сучасний розвиток української держави, соціальних інститутів і суспільних відносин визначається як період трансформаційних процесів, пошуку власного шляху розвитку та зміни цінностей. Тому зміни, які відбуваються нині, безпосередньо впливають на ціннісну свідомість молоді. Отже, проблема полягає в тому, що багато з тих цінностей, які виховувало радянське суспільство, поступово почали змінюватися, бо, з одного боку, нові соціально-економічні умови вимагають від людини таких якостей, як готовність до ризику й особисту відповідальність за свої вчинки, уміння швидко пристосовуватися до економічної кон'юнктури, готовність наполегливо працювати заради досягнення добробуту та успіху. 3 іншого боку, цінності, що в минулому мали високий ранг і пов'язувалися із закріпленими в масовій свідомості соціально-психологічними стереотипами пріоритету загального (колективного) над особистим (індивідуальним) і самореалізації особистості в праці, нині молоддю заперечуються. Криза традиційних ціннісних орієнтацій особливо яскраво проявляється у сфері праці, ставленні до роботи. I саме тому вивчення змін у системі ціннісних орієнтацій молоді сприяти виробленню ефективніших засобів і методів розв'язання молодіжних проблем зокрема і проблем суспільства взагалі.

Встановлено, що термін "ціннісні професійні орієнтації" варто розглядати як результат усвідомлення та засвоєння загальнолюдських і професійних цінностей, що стають якісним мірилом професіоналізму майбутнього фахівця, визначаючи вектор його потреб, інтересів, позиції та рівня розвитку особистості, як особливу психологічну реальність, що виконує функцію вищого критерію для орієнтації у світі та опори для особистісного та професійного самовизначення. Ціннісні орієнтації, представлені двома визначниками: фактором "его-орієнтації" та фрактором "соціо-орієнтації", кожен із яких знаходиться у взаємозв'язку з іншими, впливаючи на розвиток професійних ціннісних орієнтацій і професійно-ціннісного становлення майбутнього фахівця в цілому.

Варто зазначити, що на початку XXI ст. у формуванні особистості майбутнього фахівця ціннісні орієнтації визначають напрям і рівень активності та суттєво впливають на професійні якості. На перший план виходять цінності вищої освіти: виховання "нової людини", оптиміста, колективіста, щасливого будівника комунізму, відданого ідеям партії, інтернаціоналіста. Ці компоненти стали ціннісними орієнтирами в підготовці педагогічних кадрів суто прагматичного спрямування і санкціонувались офріційними партійними й державними структурами, які з виховною метою організовували відповідні акції. Регулярно проводилися зльоти вожатих, на яких вони мали можливість продемонструвати свою активну громадську позицію, здібності до роботи з дітьми.

Так, порівнюючи ціннісні орієнтації молоді 19601980-х років із цінностями, характерними для молодого покоління 1990-2000-х рр., варто зазначити, що:

- на сталих позиціях залишилася сім'я та робота, але відбуваються зміни в системі цінностей щодо роботи. Для $92 \%$ молоді важлива така цінність, як "висока оплата праці", і лише 28 \% означили таку, як "суспільна корисність роботи". Отже, якщо у 1970-1980 pp. 65,9 \% молоді головним у житті вважали роботу, що приносить користь суспільству, то нині для молоді важливішою стає "висока оплата праці" і втрачає позицію лідера робота, що приносить користь суспільству. Тобто, певним чином змінюється значення цінності роботи, зростають вимоги до рівня оплати праці, можливостей професійної кар'єри, самореалізації;

- набули важливої значущості коло друзів і вільний час, хобі, вечірки та відвідування кафе;

- певним чином зростає інтерес до політичного життя, хоча і політична, і громадська активність залишаються на досить низькому рівні;

- відбувається відчуження молоді від національної культури, незнання і небажання знати історію батьківщини, іï мистецтво, літературу.

Отже, варто констатувати про наявність в Україні meнденції до посилення егоїстичних мотивів у молодіжному середовищі, морального релятивізму, відчутна перевага матеріальних мотивів. Тривожною тенденцією є усунення на другий план колективістських цінностей (допомога іншим людям, сприяння розвитку суспільства тощо). Про трансформацію в системі цінностей, пов'язану зі змінами в суспільстві, свідчить те, що для більшості молоді стійким "базисом" існування тепер може бути лише особисте життя й індивідуалістські цінності. Ці молоді люди хоча і ставлять на останнє місце цінність суспільно-корисної праці, політичної активності, але зберігають моральні підвалини, що регулюють особисте й сімейне життя. Проте є й частина молоді, яка взагалі лишилась без морального та соціального фундаменту свого життя і ні в що не вірить. Ії̈ ідеал - комфорт, добробут, задоволення будь-якою ціною. В умовах соціально-економічної кризи ця частина молоді може розглядатися як "втрачене покоління". Однак це - наслідок прийняття ціннісних орієнтацій, продиктованих реаліями нашого життя. Тому перед усіма соціальними інститутами постає важке завдання: визначити базові цінності, ідеали, норми, які слід покласти в основу формування духовного світу молодої людини, і шляхи, якими 
можна було б здійснити ці перетворення. Бо саме в сучасний період трансформації соціальних систем, молодь менше уваги звертає на необхідність духовного, культурного розвитку, хоча водночас і не відхиляє його доцільності. Подібно до економічних і політичних, духовні орієнтації у свідомості й поведінці молодіжних груп перебувають у процесі складної еволюції. Тому доцільним $є$ нині подальше вивчення ціннісних орієнтацій, а саме духовних, для створення нових підходів у межах державної політики виховання молоді, уведення новацій на державному ринку праці тощо. Усе це сприятиме розв'язанню багатьох молодіжних проблем сьогодні та проблем нашого суспільства у прийдешньому, оскільки життєві цінності молоді "сьогодення" визначатимуть спосіб життя "завтра".

Встановлено, що професійне становлення молоді майбутніх фрахівців ефрективніше за умов якісної професійно-педагогічної підготовки, зміст якої наповнений аксіологічною складовою. А це неможливо без урахування в освітньому процесі досвіду застосування інноваційних педагогічних технологій як складових моделі формування ціннісних орієнтацій студентів закладу вищої освіти.

Навчання студентської молоді на основі застосування в освітньому процесі національних, моральних і загальнолюдських традицій, інноваційних педагогічних технологій не повинно бути механічним відображенням окремих педагогічних процесів і явищ. Цей аспект освітньої роботи не повинен бути позбавленим віри у сили добра й можливості особистості зберегти в собі найкращі якості.

Встановлено, що варто розробити освітні дисципліни (наприклад, дисципліна "Професійно-ціннісні орієнтації студентської молоді"), які б сприяли формуванню у студентів знань про сутність ціннісних орієнтацій особистості як феноменального особистісного утворення, його функції та види; ознайомленню зі специфічними особливостями професійно-ціннісних орієнтацій у майбутніх фахівців; розкриттю специфіки формування професійноціннісних орієнтацій у студентів ЗВО; аналізу особливостей діагностування ціннісної сфери особистості.

Доведено, що ефрективність формування професійно-ціннісних орієнтацій студентів підвищиться шляхом упровадження в освітній процес закладу вищої освіти таких педагогічних умов: забезпечення аксіологічної спрямованості змісту навчально-пізнавальної, науково-дослідницької роботи студентів, їхньої практичної підготовки; застосування інтерактивних методів і фрорм навчання, спрямованих на розвиток професійно-ціннісних орієнтацій у студентів; ефективного управління процесом формування професійно-ціннісних орієнтацій студентів ЗВО [2; 8].

Освітнє середовище закладу вищої освіти $є$ важливим чинником фрормування профресійно-ціннісних орієнтацій студентів. А відтак, головну увагу у процесі викладання навчальних курсів і залучення студентів до науково-дослідницької роботи і практичної підготовки варто акцентувати на необхідності трансорормації одержаних знань у переконання, цінності, ціннісні орієнтації та у практичну діяльність. Тому завдання як освітньої діяльності, так і науково-дослідницької роботи студентів, програм проходження ними різних видів практик слід модифікувати аксіологічною наповненістю [2-9].

В освітньому процесі закладу вищої освіти доречно застосовувати як традиційні, так і інтерактивні методи та форми навчання, спрямовані на розвиток професійноціннісних орієнтацій у студентів (проблемні лекції, лекціївізуалізації, дискусії, диспути, семінари, конференції, ігри, тренінги, захисти проєтів; моделювання конкретних ситуацій, кейс-метод).
Варто зазначити, що у процесі формування ціннісних орієнтацій студентів особливу роль відводять особистості викладача як професійно компетентної особистості зі сорормованими професійно-ціннісними орієнтаціями. Цілеспрямована діяльність викладача, який створює ціннісно-орієнтоване освітнє середовище в закладі вищої освіти з урахуванням особливостей професійної підготовки майбутніх фахівців, їхніх особистісних рис, потреб суспільного розвитку, спонукає студентів не просто запам'ятовувати інформацію, а й осмислювати її, робити певні висновки, узагальнення, висловлювати свою думку, виробляти певну позицію, прагнути до професійного самопізнання, самовдосконалення, самоосвіти та самовиховання [2; 3; 5].

На основі аналізу літературних джерел [1-10] визначено особливості формування професійно-ціннісних орієнтацій студентів ЗВО на початку XXI cm.: необхідність урахування специфіки профресійної підготовки майбутніх фахівців, доцільність створення сприятливого для розвитку ціннісної сфери освітнього середовища, урахування поліфакторності цього процесу та специфічних характерних якостей і властивостей такої соціальної групи, як студентство, вікових особливостей юнацтва як етапу особистісного становлення майбутнього фахівця.

Висновки. Еволюцію радянської педагогічної думки і практики вищої школи можна ретельно дослідити та проаналізувати через історико-педагогічну періодизацію всього спектру форм і засобів формування системи ціннісних орієнтирів учасників освітнього процесу в системі вищої освіти України радянського періоду ( $X X$ - початку XXI ст.), який продемонстрував плеяду кардинальних змін у формуванні ціннісних орієнтацій студентської молоді у ЗВО України: феномен ціннісних орієнтацій пройшов складний шлях розвитку, в аспекті розгляду його як міждисциплінарного та багатофункціонального явища.

Аналіз становлення поняття "ціннісні орієнтації" свідчить про наявність термінологічної невизначеності більшості науковців радянських часів щодо остаточного тлумачення понять "цінність", "орієнтація", "ціннісні орієнтації".

Якщо у 1920-ті рр. чітко прослідковувалася тенденція розвитку в контексті надбань світової гуманної педагогіки, то вже в середині 30-х рр. домінуючою стала радянська педагогіка, де методологічний принцип "вільного виховання" замінювався принципом партійності. Становлення та розвиток ціннісних орієнтирів радянської молоді 40-х рр. відбувалися під впливом ідеологічної пропаганди, провідним засобом якої стала культура, яка обмежена межами соцреалізму, спрямована на виховання патріотизму та подальшого утвердження ідеалів панівної комуністичної формації. Аналіз наукової літератури свідчить про відсутність вивчення аксіологічної теорії аж до кінця 50-х рр. XX ст. (1 етап).

До початку 60-х рр. XX ст. (II етап) відбувався процес зміщення ціннісних орієнтацій від релігійних уявлень про найвищу цінність Бога до верховенства державних інтересів і загально-позитивної оцінки комуністичної влади у суспільстві; в 1966 р. у вітчизняній науковій літературі з'являється й термін "ціннісні орієнтації", який використовувався для визначення системи особистісних цінностей людини.

Період "відлиги" відзначився посиленням інтересу до аналізу людських взаємовідносин, домінуючою рисою яких в педагогіці вважалося дотримання учасниками освітнього процесу загальнолюдських цінностей.

У середині 80-х рр. XX ст. (III етап), що характеризуються як час "перебудови" держави, була здійснена спроба демократизації вищої школи на основі вдосконалення існуючої соціально-політичної системи, у межах 
соціалістичного вибору. Саме за часи перебудови в радянському суспільстві був розпочатий процес переорієнтування від суто класово-ідеологічних до гуманістичних цінностей. Це пояснює звернення багатьох науковців другої половини 1980-х - початку 1990-х рр. до теоретичних розвідок поняття "ціннісних орієнтацій", аксіологічної проблематики.

Загострення інтересу до проблеми формування ціннісних орієнтацій, опосередкованої загальною суспільною ідеологією, завжди виникає на зламі політичних епох, знакових змін у суспільно-політичному житті країни та позначається на посиленні орієнтації на загальнолюдські цінності, тобто ставленні до людини як найвищої цінності.

Проблема ціннісних орієнтацій є однією з пріоритетних у сучасній науці. Гуманістичні цінності студентів закладів вищої освіти є якісно новим рівнем розвитку ціннісних орієнтацій, що містить елементи інноваційності та системного засвоєння базисних педагогічних категорій, ідей, закономірностей.

Ціннісні орієнтації особистості визначаються як прийняті й усвідомлені цінності, що обумовлюють вибір певного типу поведінки, вчинку, способу життєдіяльності. У структурі особистості ціннісні орієнтації є фрундаментом, на якому будується лінія професійної поведінки.

Специфіка формування ціннісних орієнтацій студентської молоді у ЗВО XX - початку XXI ст. полягала у вихованні необхідних ціннісних якостей особистості студента (моральний образ, світогляд, любов до науки, здібність до творчої праці)

Педагогічні надбання вітчизняних учених досліджуваного періоду щодо фрормування ціннісних орієнтацій студентської молоді у ЗВО (ідеї, принципи, методи, перспективні напрями формування ціннісних орієнтацій) можуть бути творчо використані в умовах реформування сучасної вищої школи в Україні. Формування ціннісних орієнтацій студентської молоді у ЗВО України відбувається у процесі оволодіння студентами фаховими компетенціями, педагогічною майстерністю, уміннями застосовувати набуті знання та вміння на практиці.

Отже, на основі вищевикладеного, ми вважаємо, що серед головних ціннісних орієнтацій, до чого прагне сучасна молодь $€$ добробут, сім'я, саморозвиток і самореалізація, свобода волевиявлення, демократія, тобто те, що повинно займати гідне місце у суспільстві.

Проведене дослідження засвідчило необхідність подальшого наукового пошуку технологій формування ціннісних орієнтацій студентської молоді, ціннісної рефлексії, ціннісної діяльності.
Список використаних джерел

1. Артімонова Т. Основні духовні пріоритети студентської молоді: напрями трансформацій / Т. Артімонова // Вища школа України - 2008. № 1. - С. $72-75$

2. Бех І. Д. Виховання особистості : навч. посіб. / І. Д. Бех. - К. : Либідь, 2008.

3. Гордєєва К. С. Професійні цінності в системі соціально-педагогічної роботи: психологічний аспект / К. С. Гордєєва // Гуманізація навчальновиховного процесу : зб. наук. праць / за заг. ред. В. І. Сипченка. - Слов'янськ : ДДПУ, 2014. - Вип. LXVIII, ч. І. - С. 182-188.

4. Енциклопедія освіти : енциклопедія / В. Г. Кремень. - К. : Юрінком Інтер, 2008.

5. Етика : навч посіб. / В. О. Лозовой, М. І. Панов, О. А. Стасевська та ін. К. : Юрінком Інтер, 2002. - С. 103

6. Желанова В. В. Теоретико-методологічні аспекти проблеми цінностей особистості / В. В. Желанова, А. В. Пецанова // Вісн. Луганськ. нац. пед. ун-ту ім. Т. Шевченка. - Педагогічні науки. - 2008. - № 7. - С. 114-119.

7. Калашнікова Л.Ю. Умови формування соціальної позиції студента / л. Ю. Калашнікова // Педагогіка та психологія. - 2014. - Вип. 45. - С. 125-134.

8. Соловей М. І. Професійно-педагогічна підготовка майбутнього вчителя в кредитно-модульній системі організації навчання : навч. посіб. / М. І. Соловей, В. В. Кудіна, Є. С. Спіцин. - К. : Ленвіт, 2013. - С. 148.

9. Сухомлинська О. В. Цінності у вихованні молоді та дітей: стан розроблення проблеми / О. В. Сухомлинська // Педагогіка і психологія. 1997. - № 1. - C. 105-111.

10. Цінності освіти та виховання : наук.-метод. зб. / за заг. ред. О. В. Сухомлинської. - К. 1997.

\section{References}

1. Artimonova T. Osnovni dukhovni priorytety student.s'koyi molodi: napryamy transformatsiy / T. Artimonova // Vyshcha shkola Ukrayiny. 2008. № 1. S. $72-75$.

2. Bekh I. D. Vykhovannia osobystosti: [navch. posibnyk] / I.D.Bekh. - Kyiv. Lybid', 2008. - $848 \mathrm{~s}$.

3. Hordieieva K. S. Profesiini tsinnosti $v$ systemi sotsial'no-pedahohichnoi roboty: psykholohichnyi aspekt / K. S. Hordieieva // Humanizatsiia navchal'novykhovnoho protsesu: zbirnyk naukovykh prats' / [za zah. red. prof. V. I. Sypchenka].- Slov'ians'k: DDPU, 2014. - Vypusk LXVIII. - Ch. I. - S. 182-188.

4. Entsyklopediia osvity [entsyklopediia ] / V.H.Kremen'. - Kyiv: Yurinkom Inter, 2008. - $1040 \mathrm{~s}$

5. Etyka: [navch. posibnyk] / V.O.Lozovoi, M.I.Panov, O.A.Stasevs'ka ta in. -K.: Yurinkom Inter, 2002. - 224 s. - S. 103

6. Zhelanova V.V. Teoretyko-metodolohichni aspekty problemy tsinnostey osobystosti / V.V. Zhelanova, A.V. Petsanova // Visnyk Luhans'koho natsional'noho pedahohichnoho universytetu im. T.Shevchenka (pedahohichni nauky). 2008. № 7. S. $114-119$.

7. Kalashnikova L.U. Umovy formuvannia sotsial'noi pozytsii studenta U.Kalashnikova // Pedahohika ta psykholohiia. 2014. - Vyp. 45. - S. 125-134

8. Solovei M.I., Kudina V.V., Spitsyn le.S. Profesiino-pedahohichna pidhotovka maibutn'oho vchytelia v kredytno-modul'nii systemi orhanizatsii navchannia: [navchal'nyi posibnyk] / M.I.Solovei, V.V.Kudina, le.S.Spitsyn. Kyiv: Lenvit, 2013. - 414 s. - S.148

9. Sukhomlyns'ka O. V. Tsinnosti u vykhovanni molodi ta ditey: stan rozroblennya problemy. Pedahohika i psykholohiya. 1997. № 1. S. 105-111.

10. Tsinnosti osvity i vykhovannia: [navch. posibnyk] / O.V.Sukhomlynska. - Kyiv, 1997.

Надійшла до редколегії 22.12.19

Levytska L., PhD (Pedagogical Sciences), Associate Professor

Taras Shevchenko National University of Kyiv, Kyiv, Ukraine

\section{GENESIS OF FORMATION OF VALUE ORIENTATIONS OF STUDENT YOUTH IN THE HISTORY OF DOMESTIC PEDAGOGICAL THOUGHT (XX - BEGINNING OF XXI CENTURY)}

The article deals with the historical and pedagogical aspect of the genesis of the formation of value orientations of student youth in the institutions of higher education of Ukraine from the XXth to the beginning of the XXI century. The preconditions for strengthening tendencies in the development of ideas and accumulation of the experience of formation of value orientations in higher education institutions of Ukraine in the XX - the beginning of the XXI century are characterized. The essence of the definition of "value orientation" is revealed. The changes that took place in the value orientations of youth in Ukraine are considered. The theoretical ideas are systematized and the experience of formation of value orientations of student youth in institutions of higher education of Ukraine (XX - the beginning of the XXI-st century) is generalized. the prospects of further formation of value orientations of student youth in institutions of higher education of Ukraine are substantiated.

"Professional values" are considered as a complex multilevel education, a system of coordinates and relevant regulations of the process of professional activity of a specialist. It is established that the professional values of student youth embody professional responsibility, substantive saturation of pedagogical work, its moral aspect, principles and professional relations. The functions of value orientations and peculiarities of their formation in the professional training of future specialists of the institution of higher education of Ukraine are determined.

It is established that the mechanism of formation of value orientations in student youth of the institution of higher education covers the stages: perception; response (subordinate, voluntary, response pleasure); assimilation of professional values acceptance of values, prevalence of professional values, conviction); organization of professional values conceptualization of professional values, organization of the system of professional values); use of professional values internalization of professional values, use of professional values in activity)

Keywords: values, value orientations, formation of value orientations, student youth, institutions of higher education. 